\title{
CORRESPONDENCE
}

\section{No Munich on GM crops}

\section{To the editor:}

Your editorial 'Orphans at the window' (Nat. Biotechnol. 22, 1055, 2004) presents an interesting view on potential niche markets for GM crops in Europe. Even so, as directors of companies working directly in the field, we have heard so many opinions and recommendations from various people, that the niche market proposal seems like just another idea — not new by the way —and a bit irresponsible because it is proposed as an alternative to the conventional market

을 of raw agricultural production, not as a complement.

We accept the blame for our short-minded market approach, for having completely failed to communicate with the consumers, etc. Agriculture is an economic activity, however, not just a pastime (see Table 1). Producing raw agricultural materials is a risky business. Farmers have to ensure that what is in the ground in the autumn will blossom and produce for harvest in the spring and summer, despite erratic climatic conditions, pests and diseases. We do not accept the argument that the advantages of the GM technology to the producers are negligible. For farmers, the reduction in exposure to toxic chemicals, the smaller load on the environment and the lower production costs are a big plus.

We know that the average European consumer does not pay much attention to the farmer as a producer. Often, for those who wander our beautiful rural landscapes during vacation time, the perception is that farmers are gardeners, not producers. This view of agricultural activities is more common in the United Kingdom than in France because France has a long tradition of an active rural economy (it is the second largest exporter of agricultural products in the world and the largest agricultural producer in the European Union). In fact, there are millions of Europeans whose livelihood comes directly or indirectly from the land. Ceding the seed and produce markets to non-European producers is not in their best interest. This argument applies to any region around the world; each is the best judge of its own agricultural needs and each requires access to the tools that permit the best response to those needs.

Yes, there is no problem in matching niche markets with GM products, especially, as you point out, once European legal regulations have been fully implemented. However, niche markets should be seen as a complement to core GM crop production, not a substitute for it.

\section{Pierre Malvoisin ${ }^{1}$ \& J David Grausz ${ }^{2}$ \\ ${ }^{1}$ Genoplante Valeur S.A.S, 93 rue Henri \\ Rochefort, 91025 Evry Cedex, 91057 France \\ and ${ }^{2}$ RxLS, 93 Henri Rochefort, Evry, 91057 \\ France. \\ e-mail:jdg_conseil@hotmail.com}

\section{Nature Biotechnology responds:}

We completely agree with Malvoisin and Grausz that there is no objective reason to avoid the development of 'mainstream' GM crops. Our editorial did not make the argument that the advantages of the GM technology to producers are negligible, far from it. Such crops can reduce farming risks and benefit both the environment and consumers, albeit indirectly sometimes. The fact is, though, that there are currently many greater opportunities for European (or any other) companies to sell GM staple crops in markets outside of Europe.

Our intention was to address current market conditions in Europe for GM products and to suggest a means by which agbiotech companies can best adapt to that market's conditions. On that basis, we believe commercial strategies other than mainstream crops may better suit small agbiotech companies targeting European markets.

A few agrochemical/seed companies currently dominate the GM crop market and this means that biotech companies have almost no direct access to mainstream agricultural markets. The best biotech companies can expect from developments in 'mainstream' crops is a few field trial evaluation-based R\&D contracts and some royalties on sales, but those royalties will be low and far into the

\begin{tabular}{|c|c|}
\hline Country & $\begin{array}{l}\text { Agricultural } \\
\text { production (\$ } \\
\text { billion) }\end{array}$ \\
\hline United States & 55.6 \\
\hline Europe $(15 \text { member states })^{b}$ & $54.2^{\mathrm{b}}$ \\
\hline France $^{\mathrm{C}}$ & $34.5^{c}$ \\
\hline Canada & 16.5 \\
\hline Brazil & 16.7 \\
\hline China & 14.5 \\
\hline \multicolumn{2}{|c|}{$\begin{array}{l}\text { aExports of crops \& livestock (primary \& processed) } \\
\text { in } 2002 \text { (FAO statistics). b European exports outside } \\
\text { the } 15 \text { European Union (in 2002) countries only. } \\
\text { cFrench exports include exports within Europe. }\end{array}$} \\
\hline
\end{tabular}

future. Especially in Europe, investors have no interest in helping agbiotech companies migrate up the value chain, which is what they need to do to survive commercially.

Malvoisin and Grausz have also completely misjudged the prevailing economic trend when they say that "Ceding the seed \& produce markets to non-European producers is not in their best interests." Recourse to such protectionist arguments might persuade some backward-looking nationalistic politicians to cut GM developers some slack, but they do not change the fact of increasing free trade in global markets. It is precisely because some European politicians, notably the environment ministers in member state governments, have sought to use biotech regulation as a non-tariff-barrier to trade that 'mainstream' GM crops have faced such difficulties in Europe.

The proposal for 'orphan' crops in niche markets is admittedly a compromise, not an ideal-world solution. It recognizes that many of the difficulties that agbiotech companies face are not technical but commercial and political. Ignoring those commercial and political dimensions has got European agbiotech where it is today with GM crops. We would like it to be somewhere else in the future. 